\title{
Refractory materials structural and surface changes by sulfuric acid treatment
}

\author{
E. Nushi' ${ }^{1}$, L. Gjurgjaj ${ }^{2}$, A. Mele ${ }^{1,2}$ \\ ${ }^{1}$ Center of Techniques Studies, Ivodent Academy, Rr. “Prokop Myzeqari,nr.10, Tirana, Albaniaenida.nushi@ivodent.org \\ altin.mele@ivodent.edu.al \\ ${ }^{2}$ Department of Chemistry, Faculty of Natural Sciences, University of Tirana, Bulevardi “Zog I”, nr. 25/1, 1016-Tirana, Albania \\ lorenci.gjurgjaj@fshnstudent.info
}

Prrenjas clay mineral is used as refractory material in the metal casting and is found in southeast of Albania. It has a high content on bentonite. The influence of the sulphuric acid activation on the composition, structure and surface properties of Prrenjas clay mineral is investigated in this study by means of elemental chemical analysis, X-Ray Diffractometry, IR Spectroscopy and gas adsorption- desorption measurement. $\mathrm{H}_{2} \mathrm{SO}_{4}$ concentrations of $0.143 \mathrm{M}, 0.232 \mathrm{M}, 0.371 \mathrm{M}, 0.537 \mathrm{M}, 0.734 \mathrm{M}, 0.927 \mathrm{M}$ and 1.456 $\mathrm{M}$ were used in the treatment of samples. The treatment by increasing the acid concentration brings the leaching of $\mathrm{Al}^{3+}, \mathrm{Fe}^{2+}, \mathrm{Mg}^{2+}$ from the clay structure. The specific surface area and the pore volume of the clay samples increases respectively from $83 \mathrm{~m}^{2} / \mathrm{g}$ and $0.069 \mathrm{~cm}^{3} / \mathrm{g}$ for the untreated clay to $420 \mathrm{~m}^{2} / \mathrm{g}$ and $0.384 \mathrm{~cm}^{3} / \mathrm{g}$ for the clay mineral treated with $1.456 \mathrm{M} \mathrm{H}_{2} \mathrm{SO}_{4}$ solution. New mesopores were created during the acid activation mainly in the range of $2-8 \mathrm{~nm}$. For the samples treated with $0.927 \mathrm{M}$ and 1.456 $\mathrm{M}$ solutions the increase in specific surface area and pore volume is very high. The cationic exchange capacity decreases steadily with the concentration of $\mathrm{H}_{2} \mathrm{SO}_{4}$ used for the treatment.

[1] Steudel, A., Batenburg, L. F., Fischer, H. R., Weidler, P. G., Emmerich, K. (2009). Appl. Clay Sci. 44, 105-115.

[2] Komadel, P., Schmidt, D., Madejova, J., Cicel, B. (1990). Appl. Clay Sci. 5, 113-122.

[3] Madejova, J., Budjak, J., Janek, M., Komadel, P. (1998) Spectrochim. Acta 54, 1397-1406.

[4] Kahr, G., Madsen, F. T. (1995). Applied Clay Sci., 9, Alexandre, 327-336.

Keywords: clay mineral; acid activation; surface properties 